\title{
Medicinal mushroom Phellinus linteus as an alternative cancer therapy (Review)
}

\author{
DANIEL SLIVA ${ }^{1,2,3}$ \\ ${ }^{1}$ Cancer Research Laboratory, Methodist Research Institute; ${ }^{2}$ Department of Medicine, and \\ ${ }^{3}$ Indiana University Cancer Center, Indiana University School of Medicine, Indianapolis, IN, USA
}

Received February 25, 2010; Accepted March 23, 2010

DOI: 10.3892/etm_00000063

\begin{abstract}
Alternative cancer treatment with nutritional/dietary supplements containing a wide variety of herbal products is on the rise in Western countries. Recent epidemiological studies have suggested that mushrooms may prevent against different types of cancers. Phellinus linteus is a well-known Oriental medicinal fungus with a variety of biological activities, including immunomodulatory or direct antitumor activities. The activity of $P$. linteus and its extracts is associated with the presence of polysaccharides, their peptide/protein complexes and other low molecular weight complexes. Polysaccharide fractions isolated from $P$. linteus were found to be related to the increased activity of immune cells such as the production of cytokines by macrophages and B-cells or the increased cytotoxic activity of natural killer cells. Moreover, $P$. linteus was found to modulate the expression or activity of various genes involved in cell proliferation, apoptosis, angiogenesis, invasive behavior and chemoprevention. Finally, $P$. linteus extracts demonstrated tumor regression in three independent case reports, suggesting that an extract from $P$. linteus or a dietary supplement based on the extract from $P$. linteus may have potential use for the alternative treatment of cancer.
\end{abstract}

\section{Contents}

1. Introduction

2. Phellinus linteus

3. The anticancer activity of isolated compounds

4. The anticancer activity of P. linteus extracts

5. Human studies

6. Conclusions

Correspondence to: Dr Daniel Sliva, Cancer Research Laboratory, Methodist Research Institute, $1800 \mathrm{NCapitol}$ Ave, E504, Indianapolis, IN 46202, USA

E-mail: dsliva@clarian.org

Key words: Phellinus linteus, complementary and alternative medicine, cancer

\section{Introduction}

The popularity of complementary and alternative medicine (CAM) is steadily increasing among cancer patients, and CAM represents one of the fastest growing treatment modalities in the US (1). The most commonly used CAM includes acupuncture, mind-body approaches and dietary supplements. Specifically, among cancer patients, the use of CAM ranges between 30 and $75 \%$ worldwide and includes dietary approaches, herbal and other biologically based treatments (2). For example, herbal therapies are used by more than $12 \%$ of the US population each year, resulting in annual out-ofpocket expenses above $\$ 5$ billion (3). In spite of the popularity of alternative cancer treatments with nutritional/dietary supplements among patients, sometimes based on the anecdotic evidence, CAM therapies are in many cases labeled as 'pseudoscience' (4). Therefore, rigorous scientific testing and safety evaluation of dietary supplements must be performed, after which clinicians can recommend the use of a particular dietary supplement (5).

Some of the popular, widely used dietary supplements are based on dried mushrooms or mushroom extracts. Notably, three recent epidemiological studies from Asia demonstrated an inverse correlation between mushroom intake and gastric, gastrointestinal and breast cancer, respectively (6-8). The anticancer activities of mushrooms were usually associated with the stimulation of the immune system by polysaccharides, predominantly $\beta$-glucans (9). On the other hand, mushrooms contain minerals, vitamins (e.g., thiamin, riboflavin, ascorbic acid and vitamin D), amino acids and other organic compounds (10).

\section{Phellinus linteus}

Medicinal mushroom Phellinus linteus (Berk. et Curt.) Aoshima ('meshimakobu' in Japanese) has been used in traditional Oriental medicine in Japan, China and Korea (11). The orange/yellow-colored mushroom P. linteus (PL) is a perennial fungus, which is selectively parasitic on the mulberry tree (Morus) and belongs to Hymenochaetaceae basidiomycetes which consists of 220 known species of Phellinus mainly growing in tropical areas (12). More than 40 years ago, an original study in Japan demonstrated that PL has the strongest antitumor effects compared to other mushrooms 
Table I. Anticancer activity of $P$. linteus compounds.

\begin{tabular}{|c|c|c|c|}
\hline Compound & Target cells & Biological effects & Reference \\
\hline APPL & Macrophage & Increased production of $\mathrm{NO}$, activation of PTK and PKC & 24 \\
\hline APPL & Melanoma & $\begin{array}{l}\text { Inhibition of cell adhesion and invasion, inhibition of } \\
\text { metastasis in mice }\end{array}$ & 25 \\
\hline PBP & Colon cancer & $\begin{array}{l}\text { Inhibition of proliferation and colony formation, cell cycle } \\
\text { arrest at } \mathrm{G} 2 / \mathrm{M} \text {, decrease in cyclin } \mathrm{B} 1 \text {; induction of apoptosis, } \\
\text { decrease in Bcl-2, increase in cytochrome c }\end{array}$ & 27 \\
\hline PGC & Sarcoma & Inhibition of tumor growth in mice & 15 \\
\hline PLP & Melanoma & Inhibition of tumor growth and pulmonary metastasis in mice & 23 \\
\hline $\mathrm{PPC}$ & $\begin{array}{l}\text { Splenocytes } \\
\text { Macrophage } \\
\text { NK-cells }\end{array}$ & $\begin{array}{l}\text { Induction of proliferation of B-cells } \\
\text { Induction of production of IL-1 } \beta, \mathrm{IL}-6, \mathrm{TNF}-\alpha \text { and NO } \\
\text { Enhanced cytotoxicity }\end{array}$ & 26 \\
\hline \multirow[t]{2}{*}{ Hispolon } & Epidermoid & $\begin{array}{l}\text { Inhibition of proliferation; induction of apoptosis, activation } \\
\text { of caspase- } 3\end{array}$ & 21 \\
\hline & $\begin{array}{l}\text { Breast and } \\
\text { bladder cancer }\end{array}$ & $\begin{array}{l}\text { Inhibition of proliferation, cell cycle arrest at } \mathrm{G} 2 / \mathrm{M} \text {, up-regulation } \\
\text { of } \mathrm{p} 21 \text {; induction of apoptosis, activation of caspase- } 7 \text {, } \\
\text { down-regulation of MDM2 }\end{array}$ & 28 \\
\hline $\begin{array}{l}\text { Phellifuropyranone A, } \\
\text { Meshimakobnol A and B }\end{array}$ & $\begin{array}{l}\text { Melanoma and } \\
\text { lung cancer }\end{array}$ & Inhibition of proliferation & 29 \\
\hline
\end{tabular}

APPL, acid polysaccharide; PBP, protein-bound polysaccharide; PGC, protein-glucan complex; PLP, polysaccharide; PPC, polysaccharideprotein complex.

(13). As previously reported, PL also demonstrates immunomodulatory, anti-inflammatory, anti-allergic, anti-angiogenic and anti-oxidant effects (14-18). These biological effects were found to be associated with isolated polysaccharides, proteoglycans and other organic compounds such as hispolon, caffeic acid, davallialactone, interfungins $\mathrm{A}$ and inoscavin $\mathrm{A}$ (17,19-22). Therefore, isolated compounds or complex extracts from PL demonstrate specific inhibition of signaling pathways in a variety of cancer cells.

\section{The anticancer activity of isolated compounds}

Polysaccharides isolated from $P$. linteus (PLP) significantly prolonged the survival of mice with implanted B16F10 melanoma cells. Moreover, PLP inhibited tumor growth and reduced the frequency of pulmonary metastasis. Notably, PLP was not directly toxic to cancer cells and its mechanism has been suggested to be through the stimulation of the immune response. Therefore, PLP has been recommended to patients as a natural immunotherapeutic agent without toxicity (23). The immunomodulatory effects of acid polysaccharide isolated from $P$. linteus (APPL) have been correlated with the increased production of nitric oxide (NO) and tumoricidal activity in murine peritoneal macrophages (24). In addition, genistein and staurosporine blocked NO production and tumoricidal activity in response to APPL in macrophages, suggesting that APPL activates protein tyrosine kinase (PTK) and/or protein kinase C (PKC) signaling in macrophages (24). In another study, APPL markedly suppressed the metastasis of melanoma cells in mice through the direct inhibition of cell adhesion and invasion (25). Nevertheless, APPL did not affect cell growth, suggesting that the antimetastatic properties of APPL are mediated through immunomodulation and by the direct inhibition of cell adhesion (25).

Although an oral application of the protein-glucan complex (PGC) isolated from P. linteus mycelia, consisting of $39.3 \%$ polysaccharides and $49.4 \%$ protein, suppressed the growth of S-180 sarcomas in mice, the mechanism of PGC activity was not determined (15). The polysaccharide-protein complex (PPC) extracted from $P$. linteus demonstrated immunomodulatory effects through the stimulation of the proliferation of $\mathrm{B}$-cells in murine splenocytes and the induction of production of interleukin (IL)-1 $\beta$, IL- 6 and tumor necrosis factor- $\alpha$ (TNF- $\alpha$ ) in peritoneal macrophages (26). Moreover, PPC up-regulated the macrophage-mediated tumoricidal activity by the secretion of $\mathrm{NO}$ and enhanced the natural killer (NK) cell cytotoxicity (26). On the other hand, protein-bound polysaccharide (PBP) isolated from $P$. linteus demonstrated a direct effect on cancer cells (27). Thus, PBP suppressed the proliferation and colony formation of SW480 human colon cancer cells. The inhibition of cell growth by PBP was mediated by the cell cycle arrest at $\mathrm{G} 2 / \mathrm{M}$ phase and was associated with the down-regulation of expression of cell cycle regulatory protein cyclin B1 (27). Moreover, PBP induced the apoptosis of colon cancer cells, and this effect was associated with a decrease in $\mathrm{Bcl}-2$ and an increase in the release of cytochrome c (27).

In addition to the anticancer activities of polysaccharides and their complexes (Table I), isolated low molecular weight 


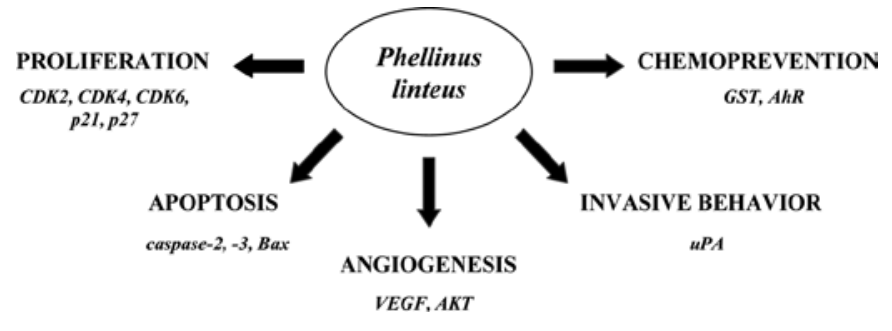

Figure 1. Biological activity of $P$. Linteus extracts.

compounds have exhibited specific effects on a variety of cancer cells. Hispolon isolated from $P$. linteus demonstrated a dose-dependent inhibition of human epidermoid KB cell proliferation (21). Furthermore, hispolon-induced apoptosis of $\mathrm{KB}$ cells was associated with the characteristic DNA laddering and with an increased amount of cells arrested in the sub-G1 phase of the cell cycle. These apoptotic events were accompanied by the collapse of mitochondrial membrane potential, the release of cytochrome $\mathrm{c}$ and the activation of caspase-3, suggesting that hispolon specifically induced the cell death of epidermoid cells through a mitochondria-mediated apoptotic pathway (21). As recently demonstrated, hispolon inhibited the proliferation and induced the apoptosis of breast and bladder cancer cells, independently of the tumor suppressor p53 status in these cells (28). The inhibition of cell growth was mediated by cell cycle arrest at the $\mathrm{G} 2 / \mathrm{M}$ phase through the up-regulation of expression of cyclin-dependent kinase inhibitor p21, whereas apoptosis was linked to the ERK1/2-dependent induction of caspase-7 and PARP in breast and bladder cancer cells (28). Notably, hispolon down-regulated the expression of the MDM2 proto-oncogene through ERK1/2-mediated MDM2 ubiquitination suggesting the use of hispolon for cancer treatment (28). Recently, isolated phellifuropyranone A and meshimakobnol $\mathrm{A}$ and $\mathrm{B}$ demonstrated antiproliferative activity against mouse melanoma and human lung cancer cells in vitro, respectively (29), although the molecular mechanism responsible for their activity was not addressed (29).

\section{The anticancer activity of $P$. linteus extracts}

As mentioned above, various biologically active compounds demonstrating immunomodulatory or direct anticancer activities were isolated from $P$. linteus. However, mushrooms in traditional Oriental medicine or in the form of dietary supplements are usually used in the form of dried mushrooms or mushroom extracts. Therefore, a variety of studies have evaluated extracts from $P$. linteus for their biological activity (Fig. 1). The anticarcinogenic/chemopreventive potentials of extracts from cultured broth and mycelia of $P$. linteus (PL I and PL II) were suggested through the induction of the phase II enzyme, glutathione S-transferase (30). Mycelium extract from $P$. linteus (MEPL) inhibited the proliferation and induced the apoptosis of neuroblastoma SK-N-MC cells, as demonstrated by chromatin condensation and an increased amount of cells in the sub-G1 phase (31). These effects were associated with the induction of cyclin-dependent kinase inhibitor p21 the proapoptotic Bax protein. Moreover, MEPL stimulated caspase-3 activity and induced the proteolytic cleavage of specific target proteins such as PARP and $\beta$-catenin (31). In another study, combination treatment with low doses of $P$. linteus extract (PL) with the anticancer drug doxorubicin synergistically induced apoptosis in prostate cancer LNCaP cells through the activation of caspase-3 and -8 (32). Therefore, the combination of PL with other chemotherapeutic drugs reduces some of the side effects of these drugs by the use of lower doses in the combination treatment with PL. Moreover, PL specifically induced apoptosis in androgen receptor (AR)-positive prostate cancer LNCaP cells through the activation of caspase-2, whereas the induction of apoptosis in AR-negative prostate cancer PC-3 cells was caspase-2 independent; this suggested that PL activates AR-dependent and AR-independent apoptotic pathways (33). In addition, a low dose of PL induced cell cycle arrest at the G1 phase through the down-regulation of expression of cyclin-dependent kinases CDK-2, -4 and -6, whereas a high dose of PL induced apoptosis of lung cancer cells (34). An aqueous extract of Cambodian P. linteus (CPL) inhibited the adhesion to gelatin and the invasion of invasive melanoma B16BL6 cells as well as B16BL6-induced platelet aggregation (11). Moreover, CPL suppressed the pulmonary metastatic colonies in C57BL/6 mice intravenously injected with B16BL6 cells. This effect was associated with the down-regulation of expression of urokinase type plasminogen activator (uPA), suggesting that CPL may inhibit metastasis via regulation of $\mathrm{UPA}$ associated with tumor cell-induced platelet aggregation (11).

We recently demonstrated that PL inhibited proliferation and colony formation of highly invasive human breast cancer MDA-MB-231 cells (35). This effect was mediated by cell cycle arrest at the $\mathrm{S}$ phase through the up-regulation of expression of cyclin-dependent kinase inhibitor p27. PL also suppressed invasive behavior of MDA-MB-231 cells by the inhibition of cell adhesion, cell migration and cell invasion through the suppression of secretion of uPA (35). Moreover, PL significantly inhibited capillary morphogenesis of human aortic endothelial cells through the down-regulation of secretion of vascular endothelial growth factor from MDA-MB-231 cells. Thus, the inhibition of angiogenesis by PL was mediated by the suppression of the serine-threonine kinase AKT in breast cancer cells (35). Finally, extracts from P. linteus mycelia (PL-1 and PL-2) suppressed the activation of the aryl hydrocarbon receptor (AhR), the receptor activated by environmental pollutants and halogenated and polycyclic hydrocarbons, resulting in AhR-dependent gene expression (36). PL-1 also suppressed AhR-dependent gene expression triggered by cigarette smoke, suggesting the use of $P$. linteous for prevention of pathologies associated with aberrant activation of AhR, including smoking-associated diseases (36). In summary, a variety of $P$. linteus extracts demonstrated inhibitory activity against signaling pathways leading to the development and progression of cancer. Although some of these extracts were only partially characterized, these studies are important, since they reflect the use of extracts in traditional Oriental medicine.

\section{Human studies}

Although three epidemiological studies have suggested that mushrooms may protect against cancer, the use of $P$. linteus 
was not addressed in these studies (6-8). In addition to the non-scientific anecdotic evidence, some sparse case reports have demonstrated the therapeutic effects of $P$. linteus extracts in patients. One case report from Japan described a positive response to $P$. linteus extract intake in a hormone refractory prostate cancer patient with rapidly progressive bone metastasis (37). Another case report from Korea described spontaneous regression of hepatocellular carcinoma (HCC) and metastatic frontal bone mass in a 65-year-old man after radiation therapy and ingestion of $P$. linteus for 18 months (38). Finally, HCC with multiple lung metastases completely regressed after 6 months in a 79-year-old man who independently ingested an extract from $P$. linteus mycelium for 1 month without any other therapy (39).

\section{Conclusions}

The therapeutic potential of isolated compounds or extracts from the medicinal mushroom $P$. linteus has been clearly demonstrated in rigorous scientific studies. In addition, the therapeutic effects of $P$. linteus extract were independently described in case reports. Collectively, these studies justify the use of dietary supplements containing $P$. linteus extract for the alternative treatment of cancer. One such dietary supplement is Breast-Mate ${ }^{\circledR}$, whose major component is an extract from $P$. linteus which has exhibited antiproliferative, anti-invasive and anti-angiogenic activities against highly invasive human breast cancer cells.

\section{References}

1. Nahleh Z and Tabbara IA: Complementary and alternative medicine in breast cancer patients. Palliat Support Care 1: 267-273, 2003

2. Richardson MA: Biopharmacologic and herbal therapies for cancer: research update from NCCAM. J Nutr 131: S3037-S3040, 2001.

3. Basch EM, Servoss JC and Tedrow UB: Safety assurances for dietary supplements policy issues and new research paradigms. J Herbal Pharmacother 5: 3-15, 2005.

4. Vickers AJ and Cassileth BR: Living proof and the pseudoscience of alternative cancer treatments. J Soc Integr Oncol 6: 37-40, 2008.

5. Michaud LB, Karpinski JP, Jones KL and Espirito J: Dietary supplements in patients with cancer: risks and key concepts, part 1. Am J Health-Syst Pharm 64: 369-381, 2007.

6. Zhang M, Huang J, Xie X and Holman CDAJ: Dietary intakes of mushrooms and green tea combine to reduce the risk of breast cancer in Chinese women. Int J Cancer 124: 1404-1408, 2009.

7. Hara M, Hanaoka T, Kobayashi M, Otani T, Adachi HY, Montani A, Natsukawa S, Shaura K, Koizumi Y, Kasuga Y, Matsuzawa T, Ikekawa T, Sasaki S and Tsugane S: Cruciferous vegetables, mushrooms and gastrointestinal cancer risks in a multicenter, hospital-based case-control study in Japan. Nutr Cancer 46: 138-147, 2003.

8. Kim HJ, Chang WK, Kim MK, Lee SS and Choi BY: Dietary factors and gastric cancer in Korea: a case-control study. Int J Cancer 97: 531-535, 2002.

9. Borchers AT, Krishnamurthy A, Keen CL, Meyers FJ and Gershwin ME: The immunobiology of mushrooms. Exp Biol Med (Maywood) 233: 259-276, 2008.

10. Mattila P, Suonpaa K and Piironen V: Functional properties of edible mushrooms. Nutrition 16: 694-696, 2000.

11. Lee HJ, Lee HJ, Lim ES, Ahn KS, Shim BS, Kim HM, Gong SJ, Kim DK and Kim SH: Cambodian Phellinus linteus inhibits experimental metastasis of melanoma cells in mice via regulation of urokinase type plasminogen activator. Biol Pharm Bull 28: 27-31, 2005 .
12. Dai YC and Xu MQ: Studies on the medicinal polypore, phellinus baumii and its kin, P. linteus. Mycotaxon 67: 191-200, 1998.

13. Ikekawa T, Nakanishi M, Uehara N, Chihara G and Fukuoka F: Antitumor action of some Basidiomycetes, especially Phellinus linteus. Jpn J Cancer Res 59: 155-157, 1968.

14. Inagaki N, Shibata $\mathrm{T}$, Itoh $\mathrm{T}$, Suzuki $\mathrm{T}$, Tanaka H, Nakamura $\mathrm{T}$, Akiyama $\mathrm{Y}$, Kawagishi $\mathrm{H}$ and Nagai $\mathrm{H}$ : Inhibition of IgE-dependent mouse triphasic cutaneous reaction by a boiling water fraction separated from mycelium of Phellinus linteus. Evid Based Complement Alternat Med 2: 369-374, 2005.

15. Nakamura T, Matsugo S, Uzuka Y, Matsuo S and Kawagishi H: Fractionation and antitumor activity of the mycelia of liquid-cultured Phellinus linteus. Biosci Biotechnol Biochem 68: 868-872, 2004.

16. Kim HG, Yoon DH, Lee WH, Han SK, Shrestha B, Kim CH, Lim MH, Chang W, Lim S, Choi S, Song WO, Sung JM, Hwang KC and Kim TW: Phellinus linteus inhibits inflammatory mediators by suppressing redox-based NF-kappaB and MAPKs activation in lipopolysaccharide-induced RAW 264.7 macrophage. J Ethnopharmacol 114: 307-315, 2007.

17. Kim GY, Han MG, Song YS, Shin BC, Shin YI, Lee HJ, Moon DO, Lee CM, Kwak JY, Bae YS, Lee JD and Park YM: Proteoglycan isolated from Phellinus linteus induces toll-like receptors 2- and 4-mediated maturation of murine dendritic cells via activation of ERK, p38, and NF-kappaB. Biol Pharm Bull 27: 1656-1662, 2004

18. Song YS, Kim S-H, Sa JH, Jin C, Lim CJ and Park EH: Anti-angiogenic, antioxidant and xanthine oxidase inhibition activities of the mushroom Phellinus linteus. J Ethnopharmacol 88: 113-116, 2003.

19. Sasaki T, Arai Y, Ikekawa T, Chihara G and Fukuoka F: Antitumor polysaccharides from some polyporaceae, Ganoderma applanatum (Pers.) Pat and Phellinus linteus (Berk. et Curt.) Aoshima. Chem Pharm Bull 19: 821-826, 1971.

20. Lee YS, Kang YH, Jung JY, Lee S, Ohuchi K, Shin KH, Kang IJ, Park JH, Shin HK and Lim SS: Protein glycation inhibitors from the fruiting body of Phellinus linteus. Biol Pharm Bull 31: 1968-1972, 2008.

21. Chen W, He FY and Li YQ: The apoptosis effect of hispolon from Phellinus linteus (Berk. et Curt.) Teng on human epidermoid KB cells. J Ethnopharmacol 105: 280-285, 2006.

22. Kim GY, Choi GS, Lee SH and Park YM: Acidic polysaccharide isolated from Phellinus linteus enhances through the up-regulation of nitric oxide and tumor necrosis factor-alpha from peritoneal macrophages. J Ethnopharmacol 95: 69-76, 2004.

23. Han SB, Lee CW, Jeon YJ, Hong ND, Yoo ID, Yang KH and Kim HM: The inhibitory effect of polysaccharides isolated from Phellinus linteus on tumor growth and metastasis. Immunopharmacology 41: 157-164, 1999.

24. Kim GY, Oh YH and Park YM: Acidic polysaccharide isolated from Phellinus linteus induces nitric oxide-mediated tumoricidal activity of macrophages through protein tyrosine kinase and protein kinase C. Biochem Biophys Res Commun 309: 399-407, 2003.

25. Han SB, Lee CW, Kang JS, Yoon YD, Lee KH, Lee K, Park SK and Kim HM: Acidic polysaccharide from Phellinus linteus inhibits melanoma cell metastasis by blocking cell adhesion and invasion. Int Immunopharmacol 6: 697-702, 2006.

26. Kim GY, Lee JY, Lee JO, Ryu CH, Choi BT, Jeong YK, Lee KW, Jeong SC and Choi YH: Partial characterization and immunostimulatory effect of a novel polysaccharide-protein complex extracted from Phellinus linteus. Biosci Biotechnol Biochem 70: 1218-1226, 2006.

27. Li G, Kim DH, Kim TD, Park BJ, Park HD, Park JI, Na MK, Kim HC, Hong ND, Lim K, Hwang BD and Yoon WH: Proteinbound polysaccharide from Phellinus linteus induces G2/M phase arrest and apoptosis in SW480 human colon cancer cells. Cancer Lett 216: 175-181, 2004.

28. Lu TL, Huang GJ, Lu TJ, Wu JB, Wu CH, Yang TC, Iizuka A and Chen YF: Hispolon from Phellinus linteus has antiproliferative effects via MDM2-recruited ERK1/2 activity in breast and bladder cancer cells. Food Chem Toxicol 47: 2013-2021, 2009.

29. Kojima K, Ohno T, Inoue M, Mizukami H and Nagatsu A: Phellifuropyranone A: a new furopyranone compound isolated from fruit bodies of wild Phellinus linteus. Chem Pharm Bull (Tokyo) 56: 173-175, 2008. 
30. Shon YH and Nam KS: Antimutagenicity and induction of anticarcinogenic phase II enzymes by basidiomycetes. J Ethnopharmacol 77: 103-109, 2001.

31. Choi YH, Huh MK, Ryu CH, Choi BT and Jeong YK: Induction of apoptotic cell death by mycelium extracts of Phellinus linteus in human neuroblastoma cells. Int J Mol Med 14: 227-232, 2004

32. Collins L, Zhu T, Guo J, Xiao ZJ and Chen CY: Phellinus linteus sensitises apoptosis induced by doxorubicin in prostate cancer. Br J Cancer 95: 282-288, 2006.

33. Zhu T, Guo J, Collins L, Kelly J, Xiao ZJ, Kim SH and Chen CY: Phellinus linteus activates different pathways to induce apoptosis in prostate cancer cells. Br J Cancer 96: 583-590, 2007.

34. Guo J, Zhu T, Collins L, Xiao ZJ, Kim SH and Chen CY: Modulation of lung cancer growth arrest and apoptosis by Phellinus linteus. Mol Carcinog 46: 144-154, 2007.

35. Sliva D, Jedinak A, Kawasaki J, Harvey K and Slivova V: Phellinus linteus suppresses growth, angiogenesis and invasive behaviour of breast cancer cells through the inhibition of AKT signalling. Br J Cancer 98: 1348-1356, 2008.
36. Mukai M, Kasai A, Hiramatsu N, Hayakawa K, Okamura M, Tagawa Y, Yao J, Nakamura T and Kitamura M: Blockade of the aryl hydrocarbon receptor pathway triggered by dioxin, polycyclic aromatic hydrocarbons and cigarette smoke by Phellinus linteus. Biol Pharm Bull 31: 1888-1893, 2008.

37. Shibata Y, Kurita S, Okugi $\mathrm{H}$ and Yamanaka H: Dramatic remission of hormone refractory prostate cancer achieved with extract of the mushroom, Phellinus linteus. Urol Int 73: 188-190, 2004.

38. Nam SW, Han JY, Kim JI, Park SH, Cho SH, Han NI, Yang JM, Kim JK, Choi SW, Lee YS, Chung KW and Sun HS: Spontaneous regression of a large hepatocellular carcinoma with skull metastasis. J Gastroenterol Hepatol 20: 488-492, 2005.

39. Kojima H, Tanigawa N, Kariya S, Komemushi A, Shomura Y, Sawada S, Arai E and Yokota Y: A case of spontaneous regression of hepatocellular carcinoma with multiple lung metastases. Radiat Med 24: 139-142, 2006. 